\title{
UK Naval Dockyards Asbestosis Study: survey of the sample population aged 50-59 years
}

\author{
C. E. ROSSITER ${ }^{1}$ AND P. G. HARRIES ${ }^{2}$ \\ From the ${ }^{1}$ MRC Pneumoconiosis Unit, Llandough Hospital, Penarth, and ${ }^{2}$ Medical Research Unit, \\ HM Naval Base, Devonport*
}

ABSTRACT As part of a general morbidity study of all civilian employees in the four Royal Naval Dockyards, the clinical, radiological and physiological effects of exposure to asbestos in 1200 men aged 50-59 years were studied in detail. The sample included all men on the Register of Asbestos Workers, one in three of those currently in occupations where intermittent exposure to asbestos may occur, and one in 30 of the remainder. The conclusions are mainly in accord with those of the comprehensive morbidity study of all the civilian dockyard workers, and show that smoking played a large part in increasing prevalence rates of radiographic, clinical, and physiological abnormalities in this population. A sub-group of 39 men, who were working as asbestos laggers or sprayers before 1957, was identified. These men showed much more extensive disease than any other sub-group, yet, even so, the smokers were worse than the non-smokers. Of these smokers, $48 \%$ had small opacities of category $1 / 1$ or more, $76 \%$ reported that they coughed during the day and $53 \%$ had crepitations; forced expiratory volume and transfer factor were also markedly reduced in these 21 smokers. Although asbestos exposure had been intermittent for the majority of the population, the prevalences of pleural thickening, small opacities, current respiratory symptoms and crepitations were shown to be related to duration of exposure to asbestos.

The widespread use for many years in naval dockyards of materials containing asbestos has intermittently exposed large numbers of employees to dust of the three main types of asbestos-amosite, chrysotile and crocidolite. The inhalation of any of these forms of asbestos can cause asbestosis and lung cancer. Exposure, particularly to crocidolite asbestos, is associated with the development of malignant mesothelioma of the pleura and peritoneum. An association between asbestos exposure and cancers at other sites in the body has been reported in the USA (Selikoff and Lee, 1978) but not confirmed in the UK. An authoritative review of asbestos-related diseases was published following a working conference in Lyon in 1972 (International Agency for Research on Cancer, 1973).

In 1965 it was discovered that cases of asbestosis were occurring at Devonport Naval Dockyard, and a radiological survey of $10 \%$ of the dockyard population showed that $4.5 \%$ of men then employed

*Now at ${ }^{1}$ Division of Computing and Statistics, Clinical Research Centre, Harrow, and ${ }^{2}$ Ranks Hovis McDougall Ltd, Croydon.

Received for publication 11 September 1978 Accepted for publication 20 February 1979 had radiographic abnormalities of the lung or pleura, probably caused by exposure to asbestos dust (Sheers and Templeton, 1968). A similar radiological survey of $10 \%$ of the whole population of the dockyards at Chatham, Portsmouth and Rosyth showed that $3.4 \%, 3.2 \%$ and $2 \%$ respectively of those populations had abnormalities attributable to the inhalation of asbestos (Harries et al., 1972). In both surveys, pleural abnormalities were many times more common than parenchymal.

After consideration of these reports, the Ministry of Defence (Navy) decided to provide a chest radiography service to every civilian employee in the four naval dockyards. As well as providing a service to individuals, the information obtained was used to estimate the prevalence of asbestos diseases in the dockyard populations (Harries et al., 1976) and as a basis for long-term studies of the relationships between cause of death and exposure to asbestos.

Because the civilian employees were so numerous (40275 subjects), a random sample was chosen for detailed study. This consisted of employees aged 50-59 years, stratified by current occupation to include people with varying degrees of asbestos exposure, drawn from each dockyard. This study was limited to those aged 50-59 years in order to 
avoid the perturbing effect of early retirement, due to ill health, in older men. This report is concerned with the detailed information obtained from the examination of the sample group.

\section{Methods}

SELECTION OF THE POPULATION

Personnel records of all employees, which included age and occupation, were used to draw the sample. The dates of enumeration of the population in each dockyard were 1 March 1972 for Devonport, 4 September 1972 for Chatham, 5 February 1973 for Portsmouth and 1 August 1973 for Rosyth.

Table 1 shows the occupations at that time which formed the basis of the occupational stratification of the sample. The same four categories of occupation were used in previous studies in these dockyards (Sheers and Templeton, 1968; Harries et al., 1972), and the sampling fractions were related to the intensity of asbestos exposure in these categories. In the sample drawn there were 14 women and 29 men who worked in places outside the main dockyard areas. Omitting these, the sample consisted of 1200 men who were then employed within the dockyards (male in-yard workers).

\section{DEFINITION OF REGISTERED ASBESTOS \\ WORKERS}

When it was discovered that cases of asbestosis were occurring in dockyard workers, each dockyard was required to compile a register of all those who had worked directly with asbestos, whether full-time or part-time. This Register of Asbestos Workers included all asbestos laggers and sprayers who had previously been exposed to high concentrations of asbestos dust, and other people in a variety of occupations whose work involved them directly with asbestos, even if only occasionally. Only workers on the Register are permitted to handle asbestos. As such, it is very unlikely that its construction would have been biased by the inclusion or exclusion of those already known to have asbestosrelated abnormalities.
After the initial formation of the Register, subjects were added, subject to a preliminary medical screening examination, if their jobs were possibly going to bring them into contact with asbestos. In many cases, the pattern of exposure to asbestos was similar to that of employees in the other occupation groups listed in Table 1.

Just over $40 \%$ of the Registered Asbestos Workers had been asbestos laggers or sprayers at some time during their dockyard employment, with half of these laggers and sprayers employed for the first time before 1957 .

\section{ADDITIONAL DATA}

Each person in the sample was asked to attend for a fuil-size chest radiograph, interview, clinical examination and lung function assessment.

Full-size chest radiographs were taken by the Medical Research Council mobile radiographic unit using $400 \mathrm{~mm} \times 400 \mathrm{~mm}$ films. Two views were taken, standard postero-anterior and right anterior oblique (Mackenzie and Harries, 1970), at between 60-80 kV, although up to $100 \mathrm{kV}$ was used for very large subjects. Of the male in-yard workers, 1103 had a full-size chest radiograph.

The interview was conducted shortly after the fullsize radiographs were taken. It was based on the MRC Respiratory Questionnaire (1960) modified to include all the questions required by the Employment Medical Advisory Service as part of their national survey of asbestos workers (Employment Medical Advisory Service, 1975). Questions were also asked to establish a full occupational history, in particular to determine what exposure to asbestos had occurred in dockyard employment, or elsewhere. It was administered to 1062 male in-yard workers.

The clinical examination was carried out on 1055 of the 1062 workers interviewed. It was usually confined to the respiratory and cardiovascular systems. The presence or absence of cyanosis, crackles, wheezes, pleural rub, finger clubbing and asbestos corns were noted. Blood pressure was measured with

Table 1 Sample population: sample drawn and applied sampling fractions with male in-yard workers and the actual sampling fractions

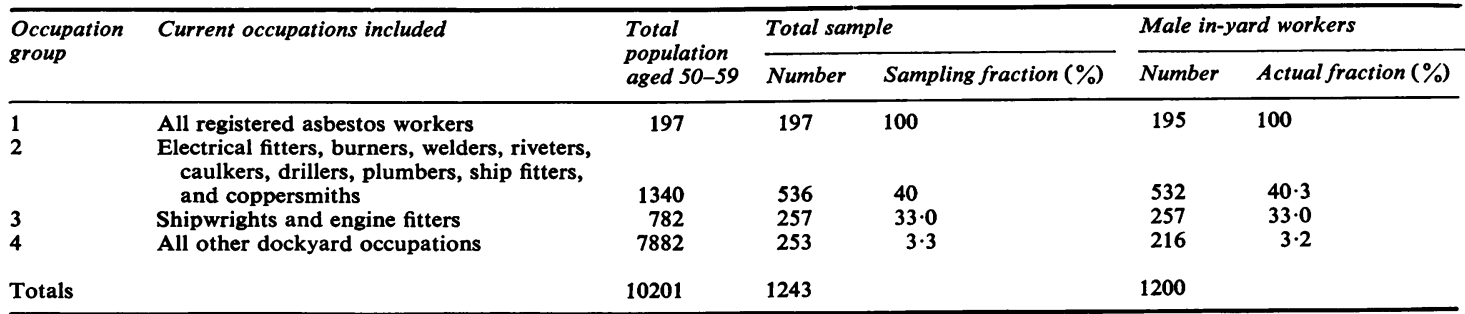


the subject seated. Height and weight were recorded in indoor clothing without shoes and jacket.

Lung function was assessed in 1042 of the male inyard workers by measurements of Forced Expiratory Volume in one second $\left(\mathrm{FEV}_{\mathbf{1} \cdot 0}\right)$, Forced Vital Capacity (FVC) and single breath Transfer Factor (TF). Values for Residual Volume (RV) and Total Lung Capacity (TLC) were obtained during the TF manoeuvre. Sixteen men did not complete the TF manoeuvre successfully.

FEV $_{1.0}$ and FVC were reported as the mean of three technically satisfactory blows following two practice attempts. Two McDermott dry spirometers were used at Devonport and one McDermott digital spirometer was used elsewhere, with a dry spirometer as reserve. All the spirometers were calibrated regularly and corrections applied for inter-instrumental differences.

TF was reported as the mean of two comparable results using the single-breath carbon monoxide method (Cotes, 1965) with one of two Morgan Resparameters. These instruments were also carefully calibrated to bring them to the same standard. However, at Devonport the use of a different gassampling technique resulted in lower values for single-breath alveolar volumes from which the residual volume and transfer factor are derived. This also affects the value of total lung capacity, which is the sum of residual volume and forced vital capacity. Values for RV and TLC are also reported as the mean of the two values obtained during the TF manoeuvres. FEV 1.0, FVC, RV and TLC are reported in litres at body temperature and standard pressure saturated with water vapour (BTPS). TF is reported in millimoles per minute per kilopascal $\left(\mathrm{mmol} \min ^{-1} \mathrm{kPa}^{-1}\right)$ at standard temperature and pressure dry (STPD).

The $100 \mathrm{~mm}$ chest radiographs of 623 members of the sample were taken by the Royal Naval Mass Radiography Unit, using a postero-anterior view only, at between $90-100 \mathrm{kV}$, but there were only 14 men who had not had a full-size radiograph taken. These have been included in subsequent analyses, giving a total response of 1117 men.

A self-administered questionnaire similar to that used at interviews was completed by 815 men. For the occupational history, the worker was asked to list all jobs since leaving school, with dates, and to provide a code number for each job from a list of codes provided. Fifty-seven men completed the selfadministered questionnaire, but were not interviewed. In the analysis of respiratory symptoms, those questionnaires have been included, making the total 1119.

\section{Results}

\section{RESPONSE RATES}

Response rates were higher in occupation groups 1 and 2, but overall $93.1 \%$ of the sample had a chest radiograph, $93.3 \%$ answered a questionnaire and $86.8 \%$ completed the tests of lung function. The following tabulations are based on the maximum number of men responding, so that the denominators vary slightly from Table to Table, but Table 2 shows the minimum number of responders by occupation group, smoking habit and duration of exposure to asbestos.

In Table 3 the proportion of these 1026 responders: in each dockyard is shown by occupation group and:

Table 2 Minimum number of responders, by occupation group, smoking habits and duration of exposure to asbestos

\begin{tabular}{|c|c|c|c|c|c|c|}
\hline \multirow[t]{2}{*}{ Smoking habits } & \multirow[t]{2}{*}{ Occupation group } & \multicolumn{4}{|c|}{ Duration of exposure to asbestos $(y r)$} & \multirow[t]{2}{*}{ Total } \\
\hline & & $0-9$ & $10-19$ & $20-29$ & $30+$ & \\
\hline Non-smokers & $\begin{array}{l}1 \\
2 \\
3 \\
4\end{array}$ & $\begin{array}{r}6 \\
22 \\
13 \\
20\end{array}$ & $\begin{array}{l}4 \\
3 \\
9 \\
3\end{array}$ & $\begin{array}{r}8 \\
15 \\
4 \\
2\end{array}$ & $\begin{array}{r}2 \\
20 \\
3 \\
3\end{array}$ & $\begin{array}{l}20 \\
60 \\
29 \\
28\end{array}$ \\
\hline Ex-smokers & $\begin{array}{l}1 \\
2 \\
3 \\
4\end{array}$ & $\begin{array}{l}12 \\
32 \\
24 \\
25\end{array}$ & $\begin{array}{r}13 \\
18 \\
12 \\
4\end{array}$ & $\begin{array}{r}13 \\
31 \\
12 \\
6\end{array}$ & $\begin{array}{r}9 \\
28 \\
9 \\
6\end{array}$ & $\begin{array}{r}47 \\
109 \\
57 \\
41\end{array}$ \\
\hline Current smokers & $\begin{array}{l}1 \\
2 \\
3 \\
4\end{array}$ & $\begin{array}{l}42 \\
70 \\
64 \\
91\end{array}$ & $\begin{array}{r}20 \\
61 \\
14 \\
8\end{array}$ & $\begin{array}{r}24 \\
66 \\
20 \\
6\end{array}$ & $\begin{array}{r}22 \\
89 \\
33 \\
5\end{array}$ & $\begin{array}{l}108 \\
286 \\
131 \\
110\end{array}$ \\
\hline Total & & 421 & 169 & 207 & 229 & 1026 \\
\hline
\end{tabular}


Table 3 Minimum number of responders, by occupation group, smoking habits and dockyard

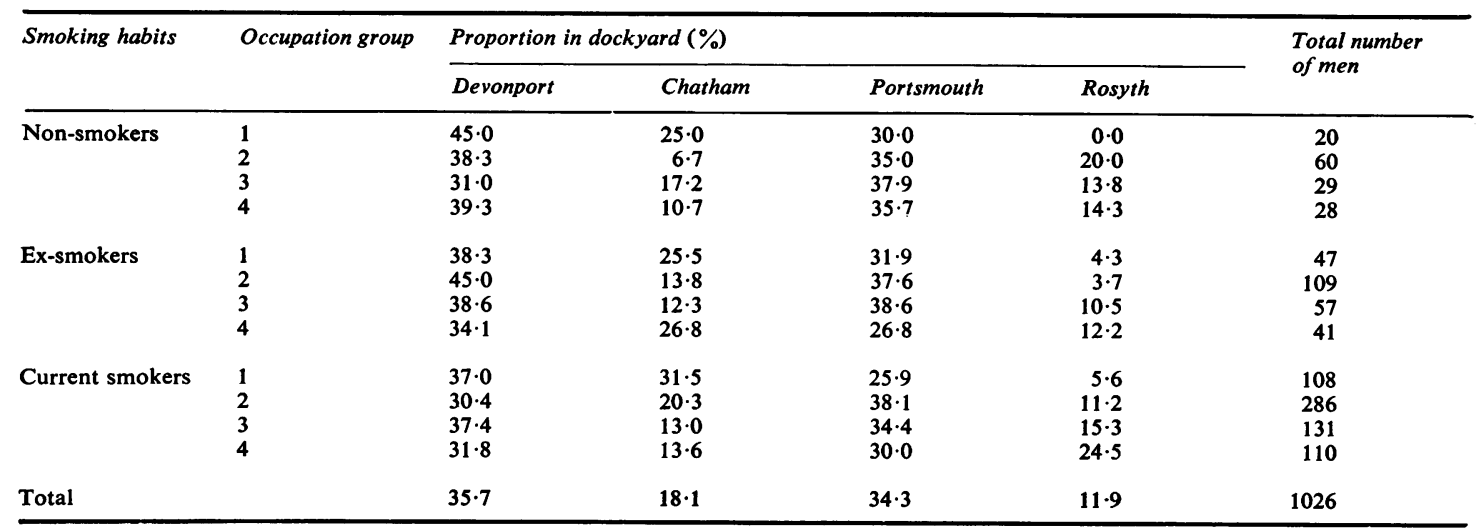

smoking habits. At Rosyth there were only eight Registered Asbestos Workers (occupation group 1) compared with 21 expected if the distribution were even, and there was an excess of workers in occupation group 4. However there is no evidence that smoking habit was related to occupation group overall $(\mathrm{P}>0 \cdot 8)$ or within dockyards $(\mathrm{P}>0 \cdot 3)$.

CLASSIFICATION OF CHEST RADIOGRAPHS Five readers* used the ILO U/C International Classification of Radiographs of Pneumoconioses, 1971 (International Labour Office, 1972) with slight modification to classify the chest radiographs independently. The modifications were that pleural thickening and calcification were recorded separately for each side of the chest and that pleural thickening was separated into two kinds, diffuse or plaques, based on the extent to which the pleural changes veiled the appearance of the lung and on the sharpness of the visible edge of the pleura.

Although techniques for averaging readings of small opacities have been developed (Oldham, 1971), they are not easily applied to other radiographic abnormalities. In the following analyses, for each type of abnormality (pleural or parenchymal) the median of the five independent readings has been used. Thus, at least three readers must have agreed on the presence of a particular abnormality for it to have been counted as present in the analyses of prevalence.

SMALL OPACITIES

One of the readers recorded rounded small opacities in the absence of irregular small opacities (in 83 men) more often than all the other readers combined.

*Drs J. C. Gilson, P. G. Harries, K. P. S. Lumley, G. Sheers and Surgeon Captain F. A. F. Mackenzie.
There were rather more Registered Asbestos Workers than men in other occupation groups among these 83 men, although no particular occupation stood out. There were also rather more smokers irrespective of occupation group.

There was just one radiograph for which three readers recorded rounded small opacities and no reader recorded irregular small opacities. Similarly, there were two readings of rounded small opacities only for a second radiograph and one reading only for a further 26. In the majority of radiographs showing small opacities, they were irregular rather than rounded. For those films where both rounded and irregular opacities were recorded, the maximum reading of profusion of either variety for each reader has been used when determining the median reading.

Three or more readers recorded category 2 or more small opacities for only eight men $(0.7 \%)$. Two of these had never been exposed to asbestos; one had undergone a rib resection thought to have been for cardiac surgery and the other had suffered from tuberculosis. The other six men were all Registered Asbestos Workers who had been asbestos laggers or sprayers before 1957. Altogether there were 39 responders who had been asbestos laggers or sprayers before 1957, 21 of whom were smokers when interviewed in 1972 or 1973 . Table 4 compares the prevalence rates of small opacities for these 39 men with those for other men. Overall, their prevalence was $30.8 \%$ compared with $2.9 \%$ for all other men. Yet, even within this small group, there were marked and significant $(P<0.02)$ differences by smoking habit, with 10 of the 21 smokers having small opacities of category $1 / 1$ or more, compared with two of 11 ex-smokers and none of the seven non-smokers. At Portsmouth there were 22 of these 39 early laggers and sprayers compared with eight, 
Table 4 Small opacities of category 1/1 or more: prevalence rates and total number of male in-yard workers

\begin{tabular}{|c|c|c|c|c|c|c|c|c|c|c|}
\hline \multirow[t]{3}{*}{ Workers } & \multicolumn{5}{|c|}{ Prevalence rates $(\%)$} & \multicolumn{5}{|c|}{ Total number of men } \\
\hline & \multicolumn{4}{|c|}{ Years of exposure to asbestos } & \multirow[t]{2}{*}{ Total } & \multicolumn{4}{|c|}{ Years of exposure to asbestos } & \multirow[t]{2}{*}{ Total } \\
\hline & $0-9$ & $10-19$ & $20-29$ & $30+$ & & $0-9$ & $10-19$ & $20-29$ & $30+$ & \\
\hline \multicolumn{11}{|c|}{ Asbestos laggers and sprayers before 1957} \\
\hline Total & 一 & $12 \cdot 5$ & $38 \cdot 9$ & $30 \cdot 8$ & $30 \cdot 8$ & - & 8 & 18 & 13 & 39 \\
\hline Non-smokers & - & 0.0 & 0.0 & 0.0 & 0.0 & - & 1 & 4 & 2 & 7 \\
\hline Ex-smokers & - & $25 \cdot 0$ & 20.0 & 0.0 & $18 \cdot 2$ & - & 4 & 5 & 2 & 11 \\
\hline Smokers & - & 0.0 & $66 \cdot 7$ & $44 \cdot 4$ & $47 \cdot 6$ & - & 3 & 9 & 9 & 21 \\
\hline All other RAW & $1 \cdot 5$ & 0.0 & $3 \cdot 4$ & $4 \cdot 8$ & $2 \cdot 1$ & 65 & 30 & 29 & 21 & 145 \\
\hline \multicolumn{11}{|c|}{ All other men (including other RAW) } \\
\hline Total & $2 \cdot 2$ & $2 \cdot 4$ & $2 \cdot 6$ & $4 \cdot 8$ & 2.9 & 457 & 170 & 195 & 230 & 1052 \\
\hline Non-smokers & 3.0 & 0.0 & 0.0 & $3 \cdot 3$ & $2 \cdot 1$ & 67 & 18 & 25 & 30 & 140 \\
\hline Ex-smokers & $3 \cdot 1$ & 0.0 & $1 \cdot 8$ & 0.0 & $1 \cdot 6$ & 97 & 46 & 56 & 51 & 250 \\
\hline Smokers & $1 \cdot 7$ & $3 \cdot 8$ & $3 \cdot 5$ & $6 \cdot 7$ & $3 \cdot 5$ & 293 & 106 & 114 & 149 & 662 \\
\hline
\end{tabular}

RAW: Registered Asbestos Workers.

eight and one at Devonport, Chatham and Rosyth respectively. This distribution is very uneven and reflects the histories of the Dockyards. However, there is no significant evidence $(P>0.7)$ of an association between dockyard and small opacities.

For all other men, there were also differences related to smoking habit for those with over 30 years of exposure $(\mathrm{P}<0.05)$. Table 5 shows that Portsmouth had a somewhat higher prevalence overall, but that this was to a considerable extent accounted for by the 22 early laggers and sprayers.

\section{PLEURAL THICKENING}

Overall, $28.5 \%$ of men had pleural thickening to some extent. There is no evidence for any association with smoking (non-smokers $27 \cdot 2 \%$, ex-smokers $31.8 \%$, smokers $27.5 \%$ ) or with occupation group (Groups 1-4: $27 \cdot 7 \%$; $31 \cdot 4 \%$; $27 \cdot 2 \%$; $23.5 \%$ ), although the prevalence rate for the group of pre1957 laggers and sprayers was somewhat higher, particularly in those with more than 30 years of exposure. Table 6 demonstrates that, overall, there was a definite association between the prevalence of pleural thickening and duration of exposure to asbestos $(P<0.001)$. There was significant $(P<0.01)$ heterogeneity in the rates by dockyard and smoking habit, with low rates for Rosyth non-smokers and Devonport smokers and a raised rate for Portsmouth ex-smokers (Table 5).

The separation of pleural thickening into diffuse or plaques shows that the diffuse kind was entirely unrelated to smoking habit, occupation group or duration of exposure to asbestos. By contrast, for pleural plaques there was a more marked correlation with duration of exposure to asbestos, and a possible excess in ex-smokers $(29.5 \%)$ compared with smokers $(23.9 \%)$ and non-smokers $(23 \cdot 1 \%)$.

Table 5 Prevalence (\%) of radiographic changes by smoking habits and dockyard: all men aged 50-59 and all men other than pre-1957 laggers and sprayers

\begin{tabular}{|c|c|c|c|c|c|c|c|}
\hline \multirow[t]{2}{*}{ Subjects } & \multirow[t]{2}{*}{ Radiographic changes } & \multirow[t]{2}{*}{ Smoking habits } & \multicolumn{4}{|l|}{ Dockyard } & \multirow[t]{2}{*}{ Total } \\
\hline & & & Devonport & Chatham & Portsmouth & Rosyth & \\
\hline \multirow[t]{3}{*}{ All men aged 50-59 } & Small opacities $1 / 1$ or more & $\begin{array}{l}\text { Non-smokers } \\
\text { Ex-smokers } \\
\text { Smokers }\end{array}$ & $\begin{array}{l}1 \cdot 8 \\
1 \cdot 8 \\
2 \cdot 1\end{array}$ & $\begin{array}{l}0.0 \\
0.0 \\
6 \cdot 3\end{array}$ & $\begin{array}{l}4 \cdot 1 \\
4 \cdot 5 \\
6 \cdot 3\end{array}$ & $\begin{array}{l}0.0 \\
0 \cdot 0 \\
5 \cdot 8\end{array}$ & $\begin{array}{l}2 \cdot 0 \\
2 \cdot 3 \\
4 \cdot 8\end{array}$ \\
\hline & Pleural thickening & $\begin{array}{l}\text { Non-smokers } \\
\text { Ex-smokers } \\
\text { Smokers }\end{array}$ & $\begin{array}{l}33 \cdot 3 \\
27 \cdot 5 \\
19 \cdot 7\end{array}$ & $\begin{array}{l}30 \cdot 0 \\
26 \cdot 1 \\
29 \cdot 4\end{array}$ & $\begin{array}{l}28 \cdot 6 \\
41 \cdot 6 \\
34 \cdot 8\end{array}$ & $\begin{array}{r}4 \cdot 8 \\
23 \cdot 5 \\
26 \cdot 7\end{array}$ & $\begin{array}{l}27 \cdot 2 \\
31 \cdot 8 \\
27 \cdot 5\end{array}$ \\
\hline & Pleural calcification & $\begin{array}{l}\text { Non-smokers } \\
\text { Ex-smokers } \\
\text { Smokers }\end{array}$ & $\begin{array}{r}17 \cdot 5 \\
5 \cdot 5 \\
3 \cdot 0\end{array}$ & $\begin{array}{l}5 \cdot 0 \\
6 \cdot 5 \\
2 \cdot 8\end{array}$ & $\begin{array}{l}4 \cdot 1 \\
6 \cdot 7 \\
4 \cdot 5\end{array}$ & $\begin{array}{l}0 \cdot 0 \\
5 \cdot 9 \\
3 \cdot 5\end{array}$ & $\begin{array}{l}8 \cdot 8 \\
6 \cdot 1 \\
3 \cdot 5\end{array}$ \\
\hline \multirow[t]{2}{*}{$\begin{array}{l}\text { All men other than pre- } 1957 \\
\text { laggers and sprayers }\end{array}$} & Small opacities $1 / 1$ or more & $\begin{array}{l}\text { Non-smokers } \\
\text { Ex-smokers } \\
\text { Smokers }\end{array}$ & $\begin{array}{l}1 \cdot 8 \\
0 \cdot 9 \\
2 \cdot 2\end{array}$ & $\begin{array}{l}0.0 \\
0.0 \\
3.6\end{array}$ & $\begin{array}{l}4 \cdot 4 \\
3 \cdot 7 \\
3 \cdot 8\end{array}$ & $\begin{array}{l}0.0 \\
0.0 \\
5.9\end{array}$ & $\begin{array}{l}2 \cdot 1 \\
1 \cdot 6 \\
3 \cdot 5\end{array}$ \\
\hline & Pleural thickening & $\begin{array}{l}\text { Non-smokers } \\
\text { Ex-smokers } \\
\text { Smokers }\end{array}$ & $\begin{array}{l}32 \cdot 7 \\
27 \cdot 4 \\
19 \cdot 6\end{array}$ & $\begin{array}{l}31 \cdot 6 \\
26 \cdot 7 \\
29 \cdot 2\end{array}$ & $\begin{array}{l}26 \cdot 7 \\
42 \cdot 7 \\
33 \cdot 8\end{array}$ & $\begin{array}{r}4 \cdot 8 \\
23 \cdot 5 \\
27 \cdot 1\end{array}$ & $\begin{array}{l}26 \cdot 4 \\
32 \cdot 0 \\
27 \cdot 0\end{array}$ \\
\hline
\end{tabular}


PLEURAL CALCIFICATION

The prevalence of pleural calcification (Table 6) was related to duration of exposure to asbestos $(P<0.001)$ but it was much higher in non-smokers than in ex-smokers and smokers $(8.8 \%, 6.1 \%$ and $3.5 \%)$. The rate in occupation group $2(7.2 \%)$ was also significantly raised $(P<0.01)$, particularly at Devonport Dockyard where $19(10.0 \%)$ of those in occupation group 2 had pleural calcification. This is shown in Table 5, in that the rate for Devonport non-smokers was much higher than the rest $(P<0.001)$ and the other rates did not differ from each other significantly $(P>0 \cdot 8)$.

\section{OTHER RADIOGRAPHIC CHANGES}

Ill-defined diaphragm and ill-defined cardiac outline were recorded for 12 and 17 men, only two of whom had both. All except three also showed some pleural change or parenchymal change of category $1 / 1$ or more. There was a slight suggestion of exposurerelated increases of prevalence, as may be seen from Table 6. However, seven of those with either illdefined diaphragm or cardiac outline were among the 39 laggers and sprayers who first worked as such before 1957, and in this group prevalence was not positively related to duration of exposure.

Costophrenic angle occlusion occurred in $7 \cdot 1 \%$ of the men, but there was no relation to smoking habits or occupation group and very little to exposure. Bilateral occlusion occurred in 15 men, 10 of whom had diffuse pleural thickening. Only one man had bilateral occlusion and no other radiographic changes.

Large opacities were recorded only occasionally and in no case by three or more readers for the same film.

\section{Respiratory symptoms}

Responses to the questions on past respiratory illness show that non-smokers had less frequently suffered from bronchitis, tuberculosis, an injury or operation to the chest or any other chest disease. The rates were generally lower for those working in Rosyth Dockyard. There was an excess of past chest illnesses among the smokers who were laggers and sprayers before 1957 (62\% compared with $46 \cdot 1 \%$ for all other smokers).

Similar information for respiratory symptoms at the time of interview is shown in Table 7 for all four dockyards combined. Smokers had the highest prevalence of cough, sputum, breathlessness and bronchitis. Non-smokers had the lowest, with exsmokers intermediate. There were no clear-cut differences between the prevalence rates in the different dockyards. By contrast, ex-smokers had more often had a chest illness lasting one week or more, some time during the last three years. The prevalences among those who were asbestos laggers or sprayers before 1957 followed the same pattern but were much higher, with, for example, 16 of the 21 smokers suffering from cough during the day.

There was no suggestion that the prevalence of cough was related to duration of dockyard employment or to years since first dockyard employment. However, there was some slight evidence of a relation to duration of exposure to asbestos but, apart from the particular sub-group of laggers and sprayers, smoking had a much greater effect on the prevalence of cough than had asbestos exposure (Table 8). Similar conclusions are reached if years since first exposure to asbestos are considered instead of duration of exposure. The pattern for

Table 6 Prevalence (\%) of radiographic changes as agreed by at least three of five readers related to duration of exposure to asbestos

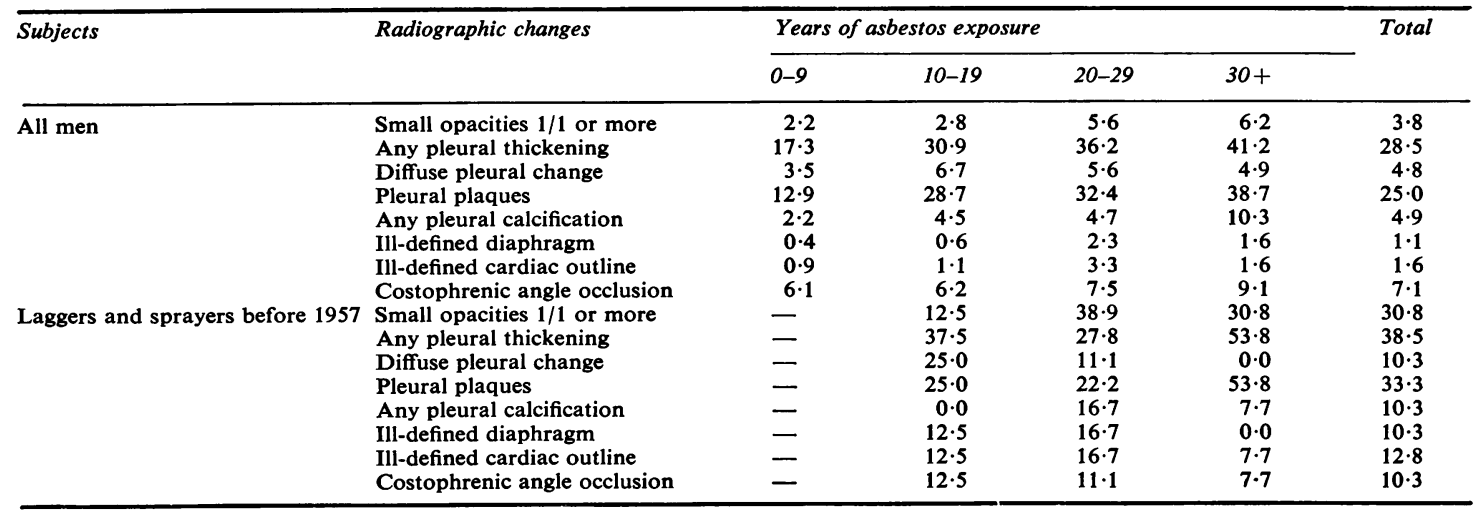


Table 7 Prevalence (\%) of respiratory symptoms by smoking habits and dockyard and for those who were laggers and sprayers before 1957

\begin{tabular}{|c|c|c|c|c|c|c|c|}
\hline \multirow[t]{2}{*}{ Symptom } & \multirow[t]{2}{*}{ Smoking habit } & \multirow{2}{*}{$\begin{array}{l}\text { All men aged } \\
50-59\end{array}$} & \multicolumn{4}{|l|}{ Dockyard } & \multirow{2}{*}{$\begin{array}{l}\text { Laggers and sprayers } \\
\text { before } 1957\end{array}$} \\
\hline & & & Devonport & Chatham & Portsmouth & Rosyth & \\
\hline Cough & $\begin{array}{l}\text { Non-smokers } \\
\text { Ex-smokers } \\
\text { Smokers }\end{array}$ & $\begin{array}{l}14 \cdot 1 \\
19 \cdot 7 \\
38 \cdot 2\end{array}$ & $\begin{array}{l}13 \cdot 8 \\
19 \cdot 3 \\
38 \cdot 8\end{array}$ & $\begin{array}{l}21 \cdot 1 \\
10 \cdot 6 \\
30 \cdot 2\end{array}$ & $\begin{array}{l}13 \cdot 7 \\
24 \cdot 2 \\
42 \cdot 1\end{array}$ & $\begin{array}{r}9 \cdot 5 \\
23 \cdot 5 \\
40 \cdot 2\end{array}$ & $\begin{array}{l}28 \cdot 6 \\
54 \cdot 5 \\
76 \cdot 2\end{array}$ \\
\hline Phlegm & $\begin{array}{l}\text { Non-smokers } \\
\text { Ex-smokers } \\
\text { Smokers }\end{array}$ & $\begin{array}{l}18 \cdot 8 \\
21 \cdot 2 \\
38 \cdot 6\end{array}$ & $\begin{array}{l}20 \cdot 7 \\
22.9 \\
39 \cdot 6\end{array}$ & $\begin{array}{l}31 \cdot 6 \\
14 \cdot 9 \\
36 \cdot 2\end{array}$ & $\begin{array}{l}17 \cdot 7 \\
24 \cdot 2 \\
42 \cdot 1\end{array}$ & $\begin{array}{r}4 \cdot 8 \\
11 \cdot 8 \\
31 \cdot 0\end{array}$ & $\begin{array}{l}14 \cdot 3 \\
54 \cdot 5 \\
66 \cdot 7\end{array}$ \\
\hline Breathlessness* & $\begin{array}{l}\text { Non-smokers } \\
\text { Ex-smokers } \\
\text { Smokers }\end{array}$ & $\begin{array}{l}10 \cdot 1 \\
14 \cdot 8 \\
14 \cdot 9\end{array}$ & $\begin{array}{r}13 \cdot 8 \\
9 \cdot 2 \\
15 \cdot 4\end{array}$ & $\begin{array}{l}15 \cdot 8 \\
10 \cdot 6 \\
12 \cdot 1\end{array}$ & $\begin{array}{r}5 \cdot 9 \\
24 \cdot 2 \\
18 \cdot 9\end{array}$ & $\begin{array}{r}4 \cdot 8 \\
11 \cdot 8 \\
8 \cdot 1\end{array}$ & $\begin{array}{l}14 \cdot 3 \\
45 \cdot 4 \\
42 \cdot 9\end{array}$ \\
\hline $\begin{array}{l}\text { Chest illness one week } \\
\text { in last } 3 \text { years }\end{array}$ & $\begin{array}{l}\text { Non-smokers } \\
\text { Ex-smokers } \\
\text { Smokers }\end{array}$ & $\begin{array}{l}16 \cdot 8 \\
22 \cdot 4 \\
19 \cdot 2\end{array}$ & $\begin{array}{l}19 \cdot 0 \\
27 \cdot 5 \\
21 \cdot 7\end{array}$ & $\begin{array}{l}21 \cdot 1 \\
19 \cdot 2 \\
22 \cdot 2\end{array}$ & $\begin{array}{l}15 \cdot 7 \\
19 \cdot 8 \\
18 \cdot 4\end{array}$ & $\begin{array}{r}9 \cdot 5 \\
11 \cdot 8 \\
9 \cdot 2\end{array}$ & $\begin{array}{l}14 \cdot 3 \\
36 \cdot 4 \\
28 \cdot 6\end{array}$ \\
\hline
\end{tabular}

* MRC dyspnoea grade 3 or worse.

†Bronchitis defined as positive response to cough and phlegm.

Table 8 Prevalence (\%) of cough by occupation group, smoking habits and duration of exposure to asbestos

\begin{tabular}{llrrrrr}
\hline $\begin{array}{l}\text { Smoking } \\
\text { habits }\end{array}$ & $\begin{array}{l}\text { Occupation } \\
\text { group }\end{array}$ & \multicolumn{6}{c}{ Years of asbestos exposure } \\
\cline { 3 - 7 } & & $0-9$ & $10-19$ & $20-29$ & $30+$ & Total \\
\hline \multirow{3}{*}{ Non- } & 1 & $0 \cdot 0$ & $0 \cdot 0$ & $12 \cdot 5$ & $50 \cdot 0$ & $10 \cdot 0$ \\
smokers & 2 & $13 \cdot 6$ & $0 \cdot 0$ & $13 \cdot 3$ & $8 \cdot 3$ & $10 \cdot 9$ \\
& 3 & $13 \cdot 3$ & $11 \cdot 1$ & $0 \cdot 0$ & $33 \cdot 3$ & $12 \cdot 9$ \\
& 4 & $24 \cdot 0$ & $33 \cdot 3$ & $0 \cdot 0$ & $25 \cdot 0$ & $23 \cdot 5$ \\
& 1 & & & & & \\
Ex- & 2 & $17 \cdot 6$ & $46 \cdot 2$ & $23 \cdot 1$ & $22 \cdot 2$ & $23 \cdot 4$ \\
smokers & 3 & $8 \cdot 3$ & $8 \cdot 3$ & $28 \cdot 1$ & $17 \cdot 2$ & $20 \cdot 9$ \\
& 4 & $10 \cdot 7$ & $60 \cdot 0$ & $16 \cdot 7$ & $33 \cdot 3$ & $15 \cdot 8$ \\
& 1 & $51 \cdot 0$ & $38 \cdot 1$ & $46 \cdot 2$ & $44 \cdot 0$ & $17 \cdot 8$ \\
Current & 2 & $33 \cdot 7$ & $43 \cdot 1$ & $34 \cdot 2$ & $44 \cdot 6$ & $39 \cdot 1$ \\
smokers & 3 & $27 \cdot 8$ & $25 \cdot 0$ & $55 \cdot 0$ & $32 \cdot 4$ & $32 \cdot 4$ \\
& 4 & $35 \cdot 4$ & $33 \cdot 3$ & $33 \cdot 3$ & $20 \cdot 0$ & $34 \cdot 5$ \\
\hline
\end{tabular}

phlegm was practically identical to that for cough, with a little evidence of a positive association with duration of exposure to asbestos, but an overwhelming effect of smoking. Thus, higher prevalences were observed in occupation groups 1 and 2, for smokers and ex-smokers, but not for nonsmokers.

Breathlessness (MRC Grade 3 or worse) was reported by a few non-smokers, with little evidence of any relation to exposure. Among ex-smokers and smokers, the prevalences were very similar overall and were lower among those with less than 10 years of exposure to asbestos $(10.5 \%)$ than among those with more than 10 years of exposure $(16.7 \%)$. This difference was similar to the slight effect of smoking. However, the pattern was very different for the pre-
1957 laggers and sprayers because the prevalences were greatly raised among the smokers and exsmokers (Table 7).

The prevalence of chest illness occurring within the last three years did not appear to be related to smoking, occupation group or duration of exposure, except among the laggers and sprayers before 1957.

The prevalence of bronchitis, defined as those with positive responses to questions on cough and phlegm, showed a relationship to exposure similar to that for those for cough and phlegm separately.

\section{Physical signs}

Crackles (rales or crepitations) were present in 99 $(9.4 \%)$ of men examined and in 13 of these $(10$ current smokers and three ex-smokers) they cleared on coughing. For the remaining 86 men $(8.2 \%$ of those examined) with persistent crackles, the only evidence that they might be an effect of asbestos exposure was that smokers who were laggers and sprayers before 1957 had a prevalence rate of $52.6 \%$ (10 out of 19 examined). This differed significantly from the average of $8 \%$ for all other groups ( $P<$ $0.001)$.

Rhonchi were recorded present in 92 men $(8.7 \%)$ and there was a marked smoking effect; nonsmokers, $5.7 \%$; ex-smokers, $5.7 \%$; current smokers, $10.6 \%$. There was no evidence of any relation to exposure or occupation group.

Finger clubbing was recorded in 44 men $(4 \cdot 1 \%)$ and, while there was a marked smoking effect (nonsmokers, $1.4 \%$; ex-smokers, $2.3 \%$; current smokers, 
$5.5 \%$ ), there was also a slight relation to exposure accounted for by four laggers and sprayers before 1957 who had finger clubbing. Pleural rub and cyanosis were recorded in six and $16 \mathrm{men}$, none of whom were non-smokers. Asbestos corns were found in 24 men, 15 of whom were among the 39 pre-1957 laggers and sprayers.

\section{Lung function}

The average values for the various lung function indices by smoking habits and dockyard are given in Table 9. Where shown, the indices have been standardised to age $55 \mathrm{yr}$ and height $1.7 \mathrm{~m}$ using the regression equations of Cotes (1965). As the age range was limited to 50-59 yr the average age of each sub-group was much the same and generally, the average height was within $2 \mathrm{~cm}$ of $1.7 \mathrm{~m}$; thus, standardisation does not influence the interpretation of these results.

As expected, current smokers had considerably lower values for one-second forced expiratory volume $\left(\mathrm{FEV}_{1.0}\right)$ than non-smokers, with ex-smokers intermediate. The only exception was at Chatham, where there were only 18 non-smokers with lung function results. In addition, occupation group 1 tended to have higher values of FEV 1.0 than had the other occupation groups for shorter durations of exposure, and lower values for the longer durations of exposure (Table 10). The pre-1957 laggers and sprayers (Table 11) had lower values of FEV 1.0 than the rest of occupation group 1, particularly among the smokers, and this enhanced the appearance of a relation to asbestos exposure throughout occupation group 1. The differences in forced vital capacity (FVC) between those with different smoking habits were rather less than for $\mathrm{FEV}_{\mathbf{1} \cdot \mathbf{0}}$, but, again, smokers had lower values than had ex- or non-smokers (Table 9). The values at Rosyth were the lowest and the patterns of values for smoking habit and occupation group, including those for the pre-1957 laggers and sprayers, were similar to those demonstrated for $\mathrm{FEV}_{1 \cdot 0}$. The FEV/FVC ratio was markedly influenced by smoking and the patterns produced by smoking, occupation group and duration of exposure reflected the greater changes in $\mathrm{FEV}_{1} \cdot 0$ than in FVC.

The values for total lung capacity (TLC) were lowest in Devonport because of the different technique used for estimating residual volume, but there were no marked effects of smoking (Table 9) or occupation group or duration of exposure, although the values for the pre-1957 laggers and sprayers were lower (Table 11$)$. Only eight (21\%) of the 39 men in this latter group worked in Devonport, compared with $36 \%$ of all men; the lower value for the pre-1957 laggers and sprayers was not, therefore, a reflection of the technical differences.

Residual volume (RV) showed the marked difference between Devonport and the other yards

Table 9 Average value of lung function by smoking habits and dockyard (standardised to age 55 yr and height $1.7 \mathrm{~m}$ )

\begin{tabular}{|c|c|c|c|c|c|c|}
\hline \multirow[t]{2}{*}{ Lung function index } & \multirow[t]{2}{*}{ Smoking habit } & \multirow{2}{*}{$\begin{array}{l}\text { All men aged } \\
50-59 \text { yr }\end{array}$} & \multicolumn{4}{|l|}{ Dockyard } \\
\hline & & & Devonport & Chatham & Portsmouth & Rosyth \\
\hline $\mathrm{FEV}_{1.0}$ (litres) (standardised) & $\begin{array}{l}\text { Non-smokers } \\
\text { Ex-smokers } \\
\text { Smokers }\end{array}$ & $\begin{array}{l}2 \cdot 90 \\
2 \cdot 76 \\
2 \cdot 56\end{array}$ & $\begin{array}{l}2 \cdot 91 \\
2 \cdot 74 \\
2 \cdot 52\end{array}$ & $\begin{array}{l}2 \cdot 67 \\
3 \cdot 02 \\
2 \cdot 76\end{array}$ & $\begin{array}{l}3 \cdot 01 \\
2 \cdot 71 \\
2 \cdot 56\end{array}$ & $\begin{array}{l}2 \cdot 81 \\
2 \cdot 54 \\
2 \cdot 38\end{array}$ \\
\hline FVC (litres) (standardised) & $\begin{array}{l}\text { Non-smokers } \\
\text { Ex-smokers } \\
\text { Smokers }\end{array}$ & $\begin{array}{l}3.95 \\
3 \cdot 92 \\
3 \cdot 83\end{array}$ & $\begin{array}{l}3 \cdot 88 \\
3 \cdot 84 \\
3 \cdot 76\end{array}$ & $\begin{array}{l}3 \cdot 90 \\
4 \cdot 24 \\
4 \cdot 01\end{array}$ & $\begin{array}{l}4 \cdot 08 \\
3 \cdot 87 \\
3 \cdot 85\end{array}$ & $\begin{array}{l}3 \cdot 86 \\
3 \cdot 83 \\
3 \cdot 66\end{array}$ \\
\hline $\mathrm{FEV}_{1 \cdot 0} / \mathrm{FVC}(\%)$ & $\begin{array}{l}\text { Non-smokers } \\
\text { Ex-smokers } \\
\text { Smokers }\end{array}$ & $\begin{array}{l}73 \cdot 2 \\
70 \cdot 2 \\
66 \cdot 8\end{array}$ & $\begin{array}{l}74 \cdot 7 \\
71 \cdot 1 \\
66 \cdot 9\end{array}$ & $\begin{array}{l}68 \cdot 9 \\
71 \cdot 3 \\
68 \cdot 6\end{array}$ & $\begin{array}{l}73 \cdot 7 \\
69 \cdot 5 \\
66 \cdot 2\end{array}$ & $\begin{array}{l}72 \cdot 3 \\
65 \cdot 9 \\
65 \cdot 1\end{array}$ \\
\hline TLC (litres) (standardised) & $\begin{array}{l}\text { Non-smokers } \\
\text { Ex-smokers } \\
\text { Smokers }\end{array}$ & $\begin{array}{l}5 \cdot 78 \\
5 \cdot 79 \\
5 \cdot 80\end{array}$ & $\begin{array}{l}5 \cdot 22 \\
5 \cdot 32 \\
5 \cdot 36\end{array}$ & $\begin{array}{l}6 \cdot 02 \\
6 \cdot 24 \\
6 \cdot 14\end{array}$ & $\begin{array}{l}6 \cdot 18 \\
6 \cdot 04 \\
5 \cdot 98\end{array}$ & $\begin{array}{l}6 \cdot 07 \\
6 \cdot 21 \\
5 \cdot 92\end{array}$ \\
\hline RV (litres) (standardised) & $\begin{array}{l}\text { Non-smokers } \\
\text { Ex-smokers } \\
\text { Smokers }\end{array}$ & $\begin{array}{l}1 \cdot 76 \\
1 \cdot 83 \\
1 \cdot 92\end{array}$ & $\begin{array}{l}1 \cdot 42 \\
1 \cdot 47 \\
1 \cdot 59\end{array}$ & $\begin{array}{l}1 \cdot 96 \\
2 \cdot 00 \\
2 \cdot 08\end{array}$ & $\begin{array}{l}2 \cdot 01 \\
2 \cdot 12 \\
2 \cdot 14\end{array}$ & $\begin{array}{l}1 \cdot 87 \\
2 \cdot 02 \\
1 \cdot 94\end{array}$ \\
\hline RV/TLC (\%) & $\begin{array}{l}\text { Non-smokers } \\
\text { Ex-smokers } \\
\text { Smokers }\end{array}$ & $\begin{array}{l}30 \cdot 7 \\
31 \cdot 3 \\
33 \cdot 0\end{array}$ & $\begin{array}{l}28 \cdot 1 \\
27 \cdot 7 \\
29 \cdot 7\end{array}$ & $\begin{array}{l}32 \cdot 3 \\
32 \cdot 1 \\
33 \cdot 9\end{array}$ & $\begin{array}{l}32 \cdot 8 \\
35 \cdot 0 \\
35 \cdot 8\end{array}$ & $\begin{array}{l}31 \cdot 4 \\
32 \cdot 2 \\
32 \cdot 6\end{array}$ \\
\hline TF $\mathrm{mmol} / \mathrm{min}^{-1} \mathrm{kPa}^{-9}$ (standardised) & $\begin{array}{l}\text { Non-smokers } \\
\text { Ex-smokers } \\
\text { Smokers }\end{array}$ & $\begin{array}{l}9 \cdot 75 \\
9 \cdot 39 \\
8 \cdot 21\end{array}$ & $\begin{array}{l}9 \cdot 19 \\
9 \cdot 20 \\
8 \cdot 10\end{array}$ & $\begin{array}{r}10 \cdot 11 \\
10 \cdot 17 \\
8 \cdot 65\end{array}$ & $\begin{array}{r}10 \cdot 09 \\
9 \cdot 32 \\
8 \cdot 21\end{array}$ & $\begin{array}{r}10 \cdot 09 \\
8 \cdot 86 \\
7 \cdot 81\end{array}$ \\
\hline
\end{tabular}


Table 10 Average values of FEV ${ }_{1 \cdot 0}$ (litres BTPS) standardised to age $55 \mathrm{yr}$ and height $1.7 \mathrm{~m}$

\begin{tabular}{|c|c|c|c|c|c|c|}
\hline \multirow[t]{2}{*}{ Smoking habits } & \multirow[t]{2}{*}{ Occupation group } & \multicolumn{4}{|c|}{ Duration of exposure to asbestos (yr) } & \multirow[t]{2}{*}{ All years } \\
\hline & & $0-9$ & $10-19$ & $20-29$ & $30+$ & \\
\hline Non-smokers & $\begin{array}{l}1 \\
2 \\
3 \\
4\end{array}$ & $\begin{array}{l}3 \cdot 08 \\
2 \cdot 98 \\
3 \cdot 19 \\
2 \cdot 91\end{array}$ & $\begin{array}{l}3 \cdot 28 \\
2 \cdot 37 \\
2 \cdot 79 \\
2 \cdot 58\end{array}$ & $\begin{array}{l}2 \cdot 92 \\
2 \cdot 57 \\
3 \cdot 34 \\
3 \cdot 02\end{array}$ & $\begin{array}{l}2 \cdot 59 \\
2 \cdot 77 \\
3 \cdot 04 \\
3 \cdot 15\end{array}$ & $\begin{array}{l}3 \cdot 01 \\
2 \cdot 77 \\
3.07 \\
2 \cdot 91\end{array}$ \\
\hline Ex-smokers & $\begin{array}{l}1 \\
2 \\
3 \\
4\end{array}$ & $\begin{array}{l}2 \cdot 94 \\
2 \cdot 73 \\
2 \cdot 97 \\
2 \cdot 79\end{array}$ & $\begin{array}{l}2 \cdot 78 \\
2 \cdot 74 \\
2 \cdot 66 \\
2 \cdot 35\end{array}$ & $\begin{array}{l}2 \cdot 49 \\
2 \cdot 73 \\
2 \cdot 82 \\
2 \cdot 77\end{array}$ & $\begin{array}{l}2 \cdot 69 \\
2 \cdot 86 \\
2 \cdot 54 \\
2 \cdot 86\end{array}$ & $\begin{array}{l}2 \cdot 72 \\
2 \cdot 76 \\
2 \cdot 81 \\
2 \cdot 75\end{array}$ \\
\hline Current smokers & $\begin{array}{l}1 \\
2 \\
3 \\
4\end{array}$ & $\begin{array}{l}2 \cdot 76 \\
2 \cdot 63 \\
2 \cdot 68 \\
2 \cdot 53\end{array}$ & $\begin{array}{l}2 \cdot 52 \\
2 \cdot 45 \\
2 \cdot 52 \\
2 \cdot 45\end{array}$ & $\begin{array}{l}2 \cdot 51 \\
2 \cdot 59 \\
2 \cdot 44 \\
2 \cdot 72\end{array}$ & $\begin{array}{l}2 \cdot 58 \\
2 \cdot 49 \\
2 \cdot 52 \\
2 \cdot 47\end{array}$ & $\begin{array}{l}2 \cdot 63 \\
2 \cdot 54 \\
2 \cdot 59 \\
2 \cdot 53\end{array}$ \\
\hline
\end{tabular}

expected for the technical reasons, and it was increased in smokers (Table 9). Only in occupation group 1 was there any evidence of an exposure relationship, with average values of $1 \cdot 74,1 \cdot 88,1 \cdot 87$ and 2.03 litres for exposures, in years, of up to 10 , 11-20, 21-30, and over 30. The RV/TLC ratio was higher in smokers, and rose with increasing duration of exposure in occupation group $1(29.6 \% ; 32.2 \%$; $33.6 \% ; 34.1 \%$ ).

Transfer factor (TF) showed the highest proportional difference between smokers and nonsmokers, and the only evidence of any difference between occupation groups or with increasing exposure to asbestos was that the pre-1957 laggers and sprayers had much the lowest values.

\section{Discussion}

The response rates in this study were much higher than those in the main morbidity study (Harries et al., 1976) where only at Devonport were there satisfactorily high responses to both chest radiographs and questionnaires. Nevertheless, the findings in this study were sufficiently similar to those of the main study to suggest that the latter results were not biassed by the low response rate.

The sample population was chosen, not only to provide groups of reasonable numerical size, enabling high response rates and more detailed examination to be achieved, but also, by selecting the age group 50-59 years, to minimise the effect of age on the various indices examined. The sampling fractions were highest for those people who were, at the time of the survey, in occupations where asbestos exposure had been greatest, in order to detect changes due to earlier asbestos exposure. Group 1, the Registered Asbestos Workers, included men previously exposed to high concentrations of

Table 11 Comparison of pre-1957 laggers and sprayers with all other men, by smoking habits

\begin{tabular}{|c|c|c|c|c|c|c|}
\hline \multirow[t]{2}{*}{ Indices } & \multicolumn{3}{|c|}{ Pre-1957 laggers and sprayers } & \multicolumn{3}{|l|}{ All other men } \\
\hline & Non-smokers & Ex-smokers & Smokers & Non-smokers & Ex-smokers & Smokers \\
\hline Number of men (range) & 7 & 11 & $18-21$ & $130-140$ & $243-251$ & $617-662$ \\
\hline $\begin{array}{l}\text { Small opacities } 1 / 1 \text { or more }(\%) \\
\text { Pleural thickening }(\%) \\
\text { Pleural calcification }(\%)\end{array}$ & $\begin{array}{r}0 \cdot 0 \\
42 \cdot 9 \\
14 \cdot 3\end{array}$ & $\begin{array}{l}18 \cdot 2 \\
27 \cdot 3 \\
18 \cdot 2\end{array}$ & $\begin{array}{r}47 \cdot 6 \\
47 \cdot 6 \\
4 \cdot 8\end{array}$ & $\begin{array}{r}2 \cdot 1 \\
26 \cdot 4 \\
8 \cdot 6\end{array}$ & $\begin{array}{r}1 \cdot 6 \\
32 \cdot 0 \\
5 \cdot 6\end{array}$ & $\begin{array}{r}3 \cdot 5 \\
27 \cdot 0 \\
3 \cdot 5\end{array}$ \\
\hline $\begin{array}{l}\text { Cough during day }(\%) \\
\text { Phlegm in morning }(\%) \\
\text { Bronchitis }(\%) \\
\text { Breathlessness (\%) } \\
\text { Chest illness in last } 3 \text { years }(\%)\end{array}$ & $\begin{array}{r}28 \cdot 6 \\
14 \cdot 3 \\
0 \cdot 0 \\
14 \cdot 3 \\
14 \cdot 3\end{array}$ & $\begin{array}{l}54 \cdot 5 \\
54 \cdot 5 \\
45 \cdot 4 \\
45 \cdot 4 \\
36 \cdot 4\end{array}$ & $\begin{array}{l}76 \cdot 2 \\
66 \cdot 7 \\
61 \cdot 9 \\
42 \cdot 9 \\
28 \cdot 6\end{array}$ & $\begin{array}{r}13 \cdot 5 \\
20 \cdot 3 \\
9 \cdot 0 \\
9 \cdot 8 \\
17 \cdot 3\end{array}$ & $\begin{array}{r}18 \cdot 3 \\
19 \cdot 9 \\
5 \cdot 2 \\
13 \cdot 1 \\
21 \cdot 5\end{array}$ & $\begin{array}{r}37 \cdot 4 \\
38 \cdot 5 \\
8 \cdot 3 \\
13 \cdot 3 \\
18 \cdot 6\end{array}$ \\
\hline $\begin{array}{l}\text { Forced expiratory volume (litres) } \\
\text { Forced vital capacity (litres) } \\
\text { Total lung capacity (litres) } \\
\text { Residual volume (litres) } \\
\text { Transfer factor (mmol/min }{ }^{-1} \mathbf{k P a}^{-1} \text { ) }\end{array}$ & $\begin{array}{l}2 \cdot 90 \\
4 \cdot 07 \\
5 \cdot 60 \\
1 \cdot 71 \\
9 \cdot 03\end{array}$ & $\begin{array}{l}2 \cdot 49 \\
3 \cdot 60 \\
5 \cdot 26 \\
1 \cdot 77 \\
8 \cdot 22\end{array}$ & $\begin{array}{l}2 \cdot 21 \\
3 \cdot 52 \\
5 \cdot 43 \\
1 \cdot 89 \\
7 \cdot 41\end{array}$ & $\begin{array}{l}2 \cdot 90 \\
3 \cdot 94 \\
5 \cdot 79 \\
1 \cdot 76 \\
9 \cdot 79\end{array}$ & $\begin{array}{l}2 \cdot 77 \\
3 \cdot 93 \\
5 \cdot 81 \\
1 \cdot 83 \\
9 \cdot 44\end{array}$ & $\begin{array}{l}2 \cdot 57 \\
3 \cdot 84 \\
5 \cdot 81 \\
1 \cdot 92 \\
8 \cdot 23\end{array}$ \\
\hline Crackles (uncleared by coughing) $(\%)$ & 0.0 & $18 \cdot 2$ & $52 \cdot 6$ & $8 \cdot 3$ & $7 \cdot 6$ & 6.9 \\
\hline
\end{tabular}

All lung function indices standardised to age $55 \mathrm{yr}$ and height $1.7 \mathrm{~m}$. 
asbestos, but then employed in other occupations with similar exposure patterns to those in other occupation groups. The laggers and sprayers were included in Group 1. Unfortunately, retrospective occupational histories were not available, so that sampling for occupation groups 2,3 and 4 had to be based solely on the occupation at that time.

Separate analysis of those working as laggers and sprayers before 1957 showed that workers in this sub-group, who had been heavily exposed to asbestos for many years, had much more extensive disease than the rest of the men on the Register of Asbestos Workers. This confirmed the findings in the separate special follow-up study of laggers and sprayers (Harries, 1970; Harries and Rossiter, 1979; Heath, 1979) which showed that the disease had progressed in the nine years of follow-up. The differences between this small group of pre-1957 laggers and sprayers and the other men studied are summarised in Table 11, which shows not only that for most indices did the pre-1957 laggers and sprayers have worse values than did other men, but also that for several indices this was particularly so for smokers. The prevalences of small opacities (category $1 / 1$ or more), bronchitis, breathlessness and crackles (not cleared by coughing) were all raised much more among the smoking than among the non-smoking pre-1957 laggers and sprayers. Forced expiratory volume, forced vital capacity and total lung capacity also showed a synergi.tic relation between smoking and the heavy asbestos exposure received by these men.

No such synergistic effect was found for breathlessness in the study of Quebec chrysotile miners and millers, and for bronchitis, heavy exposure or smoking raised the prevalence to about $50 \%$ (McDonald et al., 1972). However, in the dockyards, crocidolite as well as chrysotile asbestos was used before an effective ban was placed on crocidolite in about 1968: Weill et al. (1977) have shown that asbestos cement workers exposed to crocidolite and chrysotile had higher prevalences of small irregular opacities and significantly smaller lung volumes, lower forced expiratory flow and more reduced gas transfer than those exposed to chrysotile only. Rossiter and Berry (1978) have shown that, in an asbestos textile factory, non-smokers were less likely to develop crackles than smokers, although the amount of asbestos exposure was similar. These findings were not unexpected because of the wellknown synergistic effect of asbestos exposure and smoking on mortality from lung cancer (Saracci, 1977).

The radiographic changes in the total sample population showed that small opacities were associated with smoking and duration of exposure to asbestos, even to a certain extent after exclusion of those in the sub-group of pre-1957 laggers and sprayers. Pleural thickening was more closely related to duration of asbestos exposure than to duration of dockyard employment, and it also occurred much more often than did small opacities. The latter is in contrast to the pattern in the Quebec studies (Becklake, 1976) in which, for men aged 56-65 years, the prevalence of small irregular opacities rose from $5 \%$ to $30 \%$ and of any pleural change from $15 \%$ to $35 \%$ with increasing exposure to asbestos. However, in asbestos cement workers (Weill et al., 1977) pleural changes were much more common than parenchymal, in both the chrysotile only and the crocidolite and chrysotile exposure groups.

The prevalence of respiratory symptoms was low in non-smokers even in the men with long periods of exposure, and smoking had more effect than exposure to asbestos on the prevalence of cough, phlegm and bronchitis. However, there was evidence of a slight positive association between the prevalences of these symptoms and duration of exposure to asbestos, following the pattern seen in the main survey (Harries et al., 1976). These prevalences were much lower than those reported by McDonald et al. (1972) in Quebec asbestos workers, and by Rae et al. (1971) in British coal miners. The prevalence of breathlessness did not show such a clear relationship with smoking, and it was also much lower than in the Quebec and British coal mine studies. This possibly reflects the in iermittent pattern of exposure to dust in the dockyard workers, which was insufficient to cause widespread pulmonary fibrosis before age 60 , or it may simply be that in asbestos and coal miners, breathlessness is a more sensitive index, because their work is heavier. A history of recent chest illness showed no association with smoking or asbestos exposure.

The physical signs (crackles and finger clubbing) associated with pulmonary fibrosis did show some association with duration of exposure to asbestos, whereas wheezes which are associated with obstructive airways disease were not related to occupation or duration of exposure to asbestos. These findings are in accord with those described in the report on the heavily exposed laggers and sprayers (Harries and Rossiter, 1979; Heath, 1979). Asbestos corns were recorded in very few men, other than the pre1957 laggers and sprayers.

The results of the lung function tests reflected the medical screening before entry into the Register of Asbestos Workers (occupation group 1), and the overwhelming effect of smoking. Men in Group 1 with less than 10 years of exposure to asbestos tended to have better lung function than similar 
men in the other occupation groups, but this Group tended to show more adverse changes with longer durations of exposure than did the other occupation groups. This was largely because of the more marked response to asbestos exposure by the pre- 1957 laggers and sprayers, most of whom had worked in the dockyards for more than 20 years. Weill et al. (1975) and Becklake et al. (1972) also reported the overwhelming effect of smoking on lung function, and Becklake commented on the lack of sensitivity of the tests in detecting asbestos-related changes in smokers. However Weill et al. (1977) did report changes in lung function related to exposure to crocidolite.

Thus the present investigation has shown some similarities to previous epidemiological studies of workers exposed to asbestos, but it has also shown some differences. This observation suggests that there is no such thing as a single pattern of response to asbestos, but that both type of fibre and type of work are important determinants of biological response.

This study could not have been completed without the considerable help and cooperation of the staffs of the Medical Research Unit, Devonport, and the MRC Pneumoconiosis Unit. We are most grateful to them and to the film readers Drs J. C. Gilson, K. P. S. Lumley, G. Sheers and Surgeon Captain F. A. F. Mackenzie. We should also like to record, with thanks, the willing cooperation of the Management, Trades Unions, Dockyard Medical Centres Staff and the employees.

\section{References}

Becklake, M. R. (1976). Asbestos-related diseases of the lung and other organs: their epidemiology and implications for clinical practice. American Review of Respiratory Disease, 114, 187-227.

Becklake, M. R., Fournier-Massey, G., Rossiter, C. E., and McDonald, J. C. (1972). Lung function in chrysotile asbestos mine and mill workers of Quebec. Archives of Environmental Health, 24, 401-409.

Cotes, J. E. (1965). Lung Function. Blackwell: Oxford and Edinburgh.

Employment Medical Advisory Service (1975). A Report of the Work of the Service in 1973 and 1974. HMSO: London.

Harries, P. G. (1970). The Effects and Control of Diseases Associated with Exposure to Asbestos in a Naval Dockyard.
MD Thesis, University of London.

Harries, P. G., and Rossiter, C. E. (1979). A nine-year follow up study of men exposed to asbestos in Devonport Dockyard. Submitted to Journal of the Royal Society of Medicine.

Harries, P. G., Mackenzie, F. A. F., Sheers, G., Kemp, J. H., Oliver, T. P., and Wright, D. S. (1972). Radiological survey of men exposed to asbestos in Naval Dockyards. British Journal of Industrial Medicine, 29, 274-279.

Harries, P. G., Rossiter, C. E., and Coles, R. M. (1976). Royal Naval Dockyards Asbestosis Research Project. Clinical Research Working Party Report 1/76. Institute of Naval Medicine: Alverstoke, Gosport.

Heath, J. R. (1979). The early diagnosis of asbestosis. Submitted to Journal of the Royal Society of Medicine.

International Agency for Research on Cancer (1973). Biological Effects of Asbestos. Edited by P. Bogovski, J. C. Gilson, V. Timbrell, and J. C. Wagner. IARC: Lyon.

International Labour Office (1972). The ILO U/C International Classification of Radiographs of the Pneumoconioses, 1971. Occupational Safety and Health Series No. 22 (revised). ILO: Geneva.

McDonald, J. C., Becklake, M. R., Fournier-Massey, G., and Rossiter, C. E. (1972). Respiratory symptoms in chrysotile asbestos mine and mill workers of Quebec. Archives of Environmental Health, 24, 358-363.

Mackenzie, F. A. F., and Harries, P. G. (1970). Changing attitudes to the diagnosis of asbestos disease. Journal of the Royal Naval Medical Service, 56, 116-123.

Medical Research Council (1960). Standardised questionnaires on respiratory symptoms. British Medical Journal, $2,1665$.

Oldham, P. D. (1971). Numerical scoring of radiological simple pneumoconiosis. In Inhaled Particles III, pp. 621-630. Edited by W. H. Walton. Unwin Bros Ltd: London.

Rae, S., Walker, D. D., and Attfield, M. D. (1971). Chronic bronchitis and dust exposure in British coal mines. In Inhaled Particles III, pp. 883-894. Edited by W. H. Walton. Unwin Bros Ltd: London.

Rossiter, C. E., and Berry, G. (1978). The interaction of asbestos exposure and smoking on respiratory health. Bulletin Europien de Physiopathologie Respiratoire, 14, 197-204.

Saracci, R. (1977). Asbestos and lung cancer: an analysis of the epidemiological evidence on the asbestos-smoking interaction. International Journal of Cancer, 20, 323-331.

Selikoff, I. J., and Lee, D. H. K. (1978). Asbestos and Disease. Academic Press: New York, San Francisco, London.

Sheers, G., and Templeton, A. R. (1968). Effects of asbestos in dockyard workers. British Medical Journal, 3, 574-579.

Weill, H., Ziskind, M. M., Waggenspack, C., and Rossiter, C. E. (1975). Lung function consequences of dust exposure in asbestos cement manufacturing plants. Archives of Environmental Health, 30, 88-97.

Weill, H., Rossiter, C. E., Waggenspack, C., Jones, R. N., and Ziskind, M. M. (1977). Differences in lung effects resulting from chrysotile and crocidolite exposure. In Inhaled Particles IV, pp. 789-798. Edited by W. H. Walton. Pergamon Press: Oxford and New York. 